\title{
THE EFFECT OF INDIVIDUAL, ENVIRONMENTAL AND ENTREPRENEURIAL BEHAVIOR FACTORS ON BUSINESS PERFORMANCE OF CASSAVA SMES AGROINDUSTRY IN PADANG CITY
}

\author{
Reza Mardhiyah Amir ${ }^{* 1}$, Burhanuddin*), and Wahyu Budi Priatna*) \\ *) Departement of Agribusiness. Faculty of Economics and Management, Bogor Agricultural University \\ Jl. Kamper, Wing 4 Level 5 Campus of IPB Darmaga Bogor 16680
}

\begin{abstract}
The purpose of this research was to analyze the effect of individual factors, enviromental factors, entrepreneurial behavior on business performance of cassava SMEs agroindustry in Padang. This research was conducted in January-March 2017, and the number of respondents was 53 entrepreneurs. The analysis method used was quantitative analysis using Partial Least Square (PLS) version 2.0. The results showed individual factors have positive and significant effect on entrepreneurial behavior with the influence coefficient 0.430 . The most dominant individual factor that reflected entrepreneurial behavior was the experience with the load factor $(\lambda) 0.877$. Environmental factors have a positive and significant effect on individual factors with the influence coefficient 0.478 . Environmental factors have a positive and significant effect on entrepreneurial behavior with the influence coefficient 0.405 . The most dominant environmental factor that affected entrepreneurial behavior was training with the load factor $(\lambda) 0.840$. The entrepreneurial behavior factor has a positive and significant effect on business performance with influence coefficient 0.575 . The most dominant entrepreneurial behavior that influenced the business performance was the innovativeness with the load factor $(\lambda) 0.774$.
\end{abstract}

Keywords: individual factor, environmental factor, entrepreneurial behavior, business performance, partial least square (PLS)

\begin{abstract}
Abstrak: Tujuan dari penelitian ini adalah untuk menganalisis pengaruh faktor individu, faktor lingkungan, perilaku kewirausahaan terhadap kinerja usaha UMKM olahan ubi kayu di Kota Padang. Penelitian ini dilakukan pada bulan Februari-Maret 2017, dengan jumlah responden sebanyak 53 pelaku usaha. Metode yang digunakan adalah metode kuantitatif dengan menggunakan Partial Least Square (PLS). Hasil penelitian membuktikan bahwa kinerja usaha olahan ubi kayu ditentukan oleh perilaku kewirausahaan dengan koefisien pengaruh perilaku kewirausahaan sebesar 0.575 . Variabel yang paling dominan mencerminkan perilaku kewirausahaan adalah inovatif $(\lambda)$ sebesar 0.793. Perilaku kewirausahaan dipengaruhi oleh faktor individu dengan koefisien pengaruh sebesar 0.430. Variabel yang paling dominan mencerminkan faktor individu adalah pengalaman dengan muatan faktor ( $\lambda$ ) sebesar 0.877. Faktor individu dipengaruhi oleh faktor lingkungan dengan koefisien pengaruh sebesar 0.478 . Variabel yang paling dominan mencerminkan faktor lingkungan adalah dukungan pelatihan ( $\lambda$ ) sebesar 0.839 .
\end{abstract}

Kata kunci: faktor individu, lingkungan, perilaku kewirausahaan, kinerja usaha, partial least square (PLS)

\footnotetext{
${ }^{1}$ Corresponding author:

Email: rezamardhiyaah@gmail.com
} 


\section{INTRODUCTION}

In th early $20^{\text {th }}$ century, entrepreneurship became one of the interesting aspects to learn because of its role in economic development. A successfull entrepreneur is a person who can improve their performance well. Indonesia is a country that supports the formation of entrepreneurship. It can be seen from many government programs that massively support to increase the number of entrepreneurs, one of which is in the field of food and beverage manufacturing industry.

Food and beverage manufacturing industry in Indonesia generally is on small, micro entrepreneurship (SMEs). SMEs is one of the strategic economic sectors that are related to many people's lives, so it can be an important national economic development. Similar to this opinion, Karunanithy and Jeyaraman (2013) stated that small dan micro entrepreneurships are the back bone of all developing nations. SMEs is also a big economic actor in Indonesian economic development and has proved to be a national economic safeguarding key and also a deciminator of post-crisis economic growth.

One of the food and beverage industries in the SME's scale in Indonesia is cassava agroindustry. The potential of cassava in Indonesia is very big in terms of the main sources of carbohydrate food after rice and corn. In the food and beverage industry, cassava can be processed into various products such as crackers, crisps and sweet potato starch or tapioca flour. The existence of these preparations can give added value to the sale of agricultural products.

Cassava is one of the food crops that have opportunity to be developed in West Sumatra in the context of agribusiness, because of the availability of marketing. If this condition can be utilized properly, it will be able to provide income and also improve the regional economy. Padang City is one of the areas that produce and process cassava in West Sumatra. Cassava is a superior product of the region that becomes the local brand of Padang City. This cassava agroindustry can not only help farmers in marketing and increasing added value, but also reducing unemployment rates in the area around the industry. Seeing the important role of cassava agroindustry, it is necessary for entrepreneurs who have entrepreneurial behavior to improve their business performance to develop their business. However, in the implementation there are still some problems: 1) the availability and price of raw materials that often fluctuate, 2) lack of access to capital, and 3) the use of production equipment that is still manual. Although entrepreneurs have various motivations in doing their business, the facts show that there is still business that is poorly managed by entrepreneurs. Entrepreneurs' motivation in general is just to fulfill their daily needs, not for business oriented so the business does not run well. Entrepreneurs also do not have a financial book and do not separate family expenses from business expenses, so that business capital is often used for daily purposes. This shows that the business has not been managed professionally, so its business performance is also not optimal. However, some of these problems do not dampen the entrepreneurs' intention to keep running their business up to the present.

Increasing business performance can be seen from the matters that underlie a person to be an entrepreneur, i.e. individual factors, environmental factors and entrepreneurial behavior factors. Gupta and Muita (2012) and Mothibi (2015) in their research stated that individual factors and environmental factors and entrepreneurial behavior factors had an effect on business performance of SMEs. Education, business experience, duration of business running have an effect on SMEs business performance. Based on the description, it is necessary to examine the effect of individual factors, environmental factors, and entrepreneurial behavior of entrepreneurs on the business performance of cassava SMEs agroindustry. The purpose of this research was to analyze the effect of individual factors, environmental factors and entrepreneurial behavior on business performance.

This research has been done in Padang City as a case study, so the results of this study cannot infer the conditions in other regions. In addition, respondents used in this research are entrepreneurs who run cassava business in SMEs agroindustry.

\section{METHODS}

The data used in this research include primary and secondary data, both qualitative and quantitative. The primary data source included all data collection methods from the original source and was collected specifically for the purpose of the research. Primary data was obtained through direct interviews of the target respondents by using the Likert scale of 5 points. Primary data consisted of respondents' characteristics, 
entrepreneurial behavior and business performance. Secondary data was the data that had been published and collected for research's purposes. Secondary data was obtained from Central Bureau of Statistics, Department of Industry, Trade, Mine and Energy of Padang City, Department of MSMEs and Cooperative of Padang City, literature books, journals, dissertations, thesis, internet and other literatures that were relevant to the research .

Determination of respondents in this study was done by using nonprobability sampling technique, a sampling technique that does not give equal opportunity for every element of population member (Sugiyono, 2010). Nonprobability sampling technique used was census method in which all samples would become respondents (Sugiyono, 2010). A number of 53 entrepreneurs of cassava SMEs agroindustry (Department of Manpower and Industry, 2015) became respondents chosen from all Cassava SMEs agroindustry in Padang that were still productive. The entrepreneurs were the managers and owners of cassava SMEs agroindustry businesses, which produce cassava continuously.
The data that have been collected will be processed further to get the result which is used as the answer of the research problem using Partial Least Square (PLS) analysis method. The PLS method is a powerful analytical method because it is not based on many assumptions. The data used should not have multivariate normal distribution or indicator with scale, ordinal, interval and ratio can be used as sample in this model and samples with PLS approach should not be large (Ghozali and Latan, 2013).

There are two stages in the evaluation of measurement model, namely model of measurement (outer model) and model of structural (inner model). The measurement model describes the relationship between latent variables with manifest variables or observed variables, whereas structural models explain the relationship between latent variables. Latent variable is a variable that cannot be directly observed, and it can be seen by using indicator variable (manifest). Variables in this research come from journals, proceedings, dissertation, thesis, reports and books. Variables used in the research can be seen in Table 1.

Table 1. Research variables of the effects of individual factors, environmental factors, and entrepreneurial behavior on business performance of cassava SMEs agroindustry

\begin{tabular}{|c|c|}
\hline Manifest Variables & Explanation \\
\hline $\begin{array}{l}\text { Individual Factor (IF): } \\
\text { Education (EDU) } \\
\text { Experience (EXP) } \\
\text { Motivation (MOT) }\end{array}$ & $\begin{array}{l}\text { Formal education rate of entrepreneurs (year) } \\
\text { Duration of respondents running their business (year). } \\
\text { Encouragement or entrepreneurial desire to run their business }\end{array}$ \\
\hline $\begin{array}{l}\text { Environmental Factor (EF): } \\
\text { Inputs availability (IA) } \\
\text { Training Support (TS) } \\
\text { Counseling Support (CS) } \\
\text { Capital Support(CPS) } \\
\text { Promotion Support (PS) } \\
\text { Marketing Support (MS) } \\
\text { Business Regulation (RH) }\end{array}$ & $\begin{array}{l}\text { Level of ease in getting input materials. } \\
\text { Government attention in the form of training about cassava processing business. } \\
\text { Government attention in the form of counseling about cassava processing business. } \\
\text { Government attention in the form of capital and tools production. } \\
\text { Government attention in the form of promotion. } \\
\text { Government attention in the form of marketing. } \\
\text { Government policy or regulation that support business development.in the form of } \\
\text { price regulation and marketing regulation. }\end{array}$ \\
\hline $\begin{array}{l}\text { Cohesiveness among entrepreneurs } \\
\text { (CE) }\end{array}$ & Mutual support between entrepreneurs. \\
\hline $\begin{array}{l}\text { Entrepreneurial Behavior (EB): } \\
\text { Opportunities rensponsiveness (OR) } \\
\text { Inovativeness (INV) } \\
\text { Risk taking (RT) }\end{array}$ & $\begin{array}{l}\text { Ability in knowing opportunities or opportunities oriented. } \\
\text { Entrepreneurs ability to create idea, product or new production. } \\
\text { The courage to take risks in doing business by carefully calculating and preparing } \\
\text { for the solving problems. }\end{array}$ \\
\hline Persistence in doing business (PB) & $\begin{array}{l}\text { Persistence level of effort, discipline and patience in running and facing business } \\
\text { problems. }\end{array}$ \\
\hline $\begin{array}{l}\text { Business Performance (BP): } \\
\text { Market expansion (ME) } \\
\text { Income increasing (II) } \\
\text { Competitive advantage (CA) }\end{array}$ & $\begin{array}{l}\text { Ability to gain new market share or marketing expansion } \\
\text { Income rised from the previous. } \\
\text { Products having many advantages over other products, not easily imitated, not easily } \\
\text { replaced. }\end{array}$ \\
\hline
\end{tabular}

Sources: Riyanti (2003); Noersasongko (2005); Sapar (2006); Alma (2010); Dirlanudin (2010); Sumantri (2013); Puspitasari (2013); Mothibi (2015); Wahyuningsih (2016). 
The development of cassava SMEs agroindustry in Padang City has huge potential from the availability of raw materials and the role of industry for community. The existence of this industry is expected to be able to lift production as well as direction of local cassava commodity development as raw materials. Besides assisting the marketing of production, cassava agroindustry can also reduce unemployment around the industrial environment. However, the opportunity to develop the cassava agroindustry is not followed by entrepreneurs' increasing performance. The focus of this study was to look at what entrepreneurs did in their business activities and their effects on performance, while the characteristics of entrepreneurship became one of the factors that formed their behavior. Entrepreneurial behavior were strongly influenced by individual factors and also by the environment called environmental factors. Environmental factors affected not only entrepreneurial behavior but also individual and business performance, while business performance was also influenced by entrepreneurial behavior. This relationship can be seen in Figure 1.

\section{RESULTS}

\section{Analysis of the Effects of Individual Factors, Environmental Factors, Entrepreneurial Behavior and Business Performance with Partial Least Square (PLS) Approach}

PLS can be used to explain the presence or absence of relationships between variables. The first stage is measurement model evaluation, that is a phase to make sure that the construction used in this research fulfill the valid and reliable criteria. One of them can be seen from the value of loading factor $(\lambda)$ with the standard 0.5 (Ghozali and Latah, 2013). The model of measuring the effects of individual factors, environmental factors, and entrepreneurial behavior factors in the cassava SMEs agroindustry after being re-estimated can be seen in Figure 2.

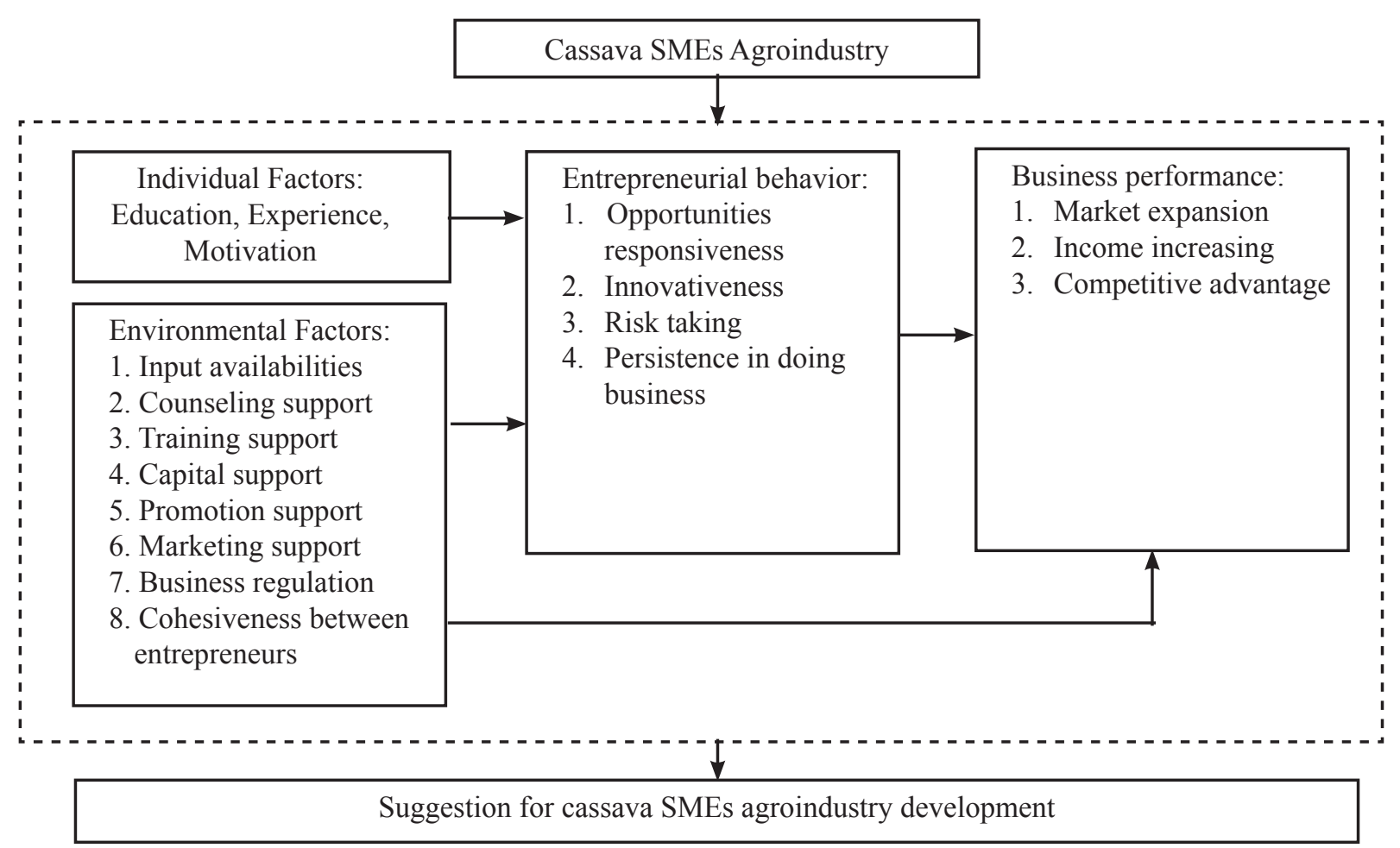

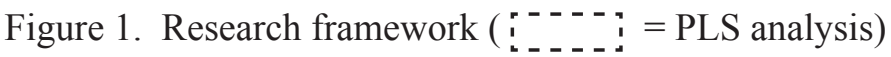




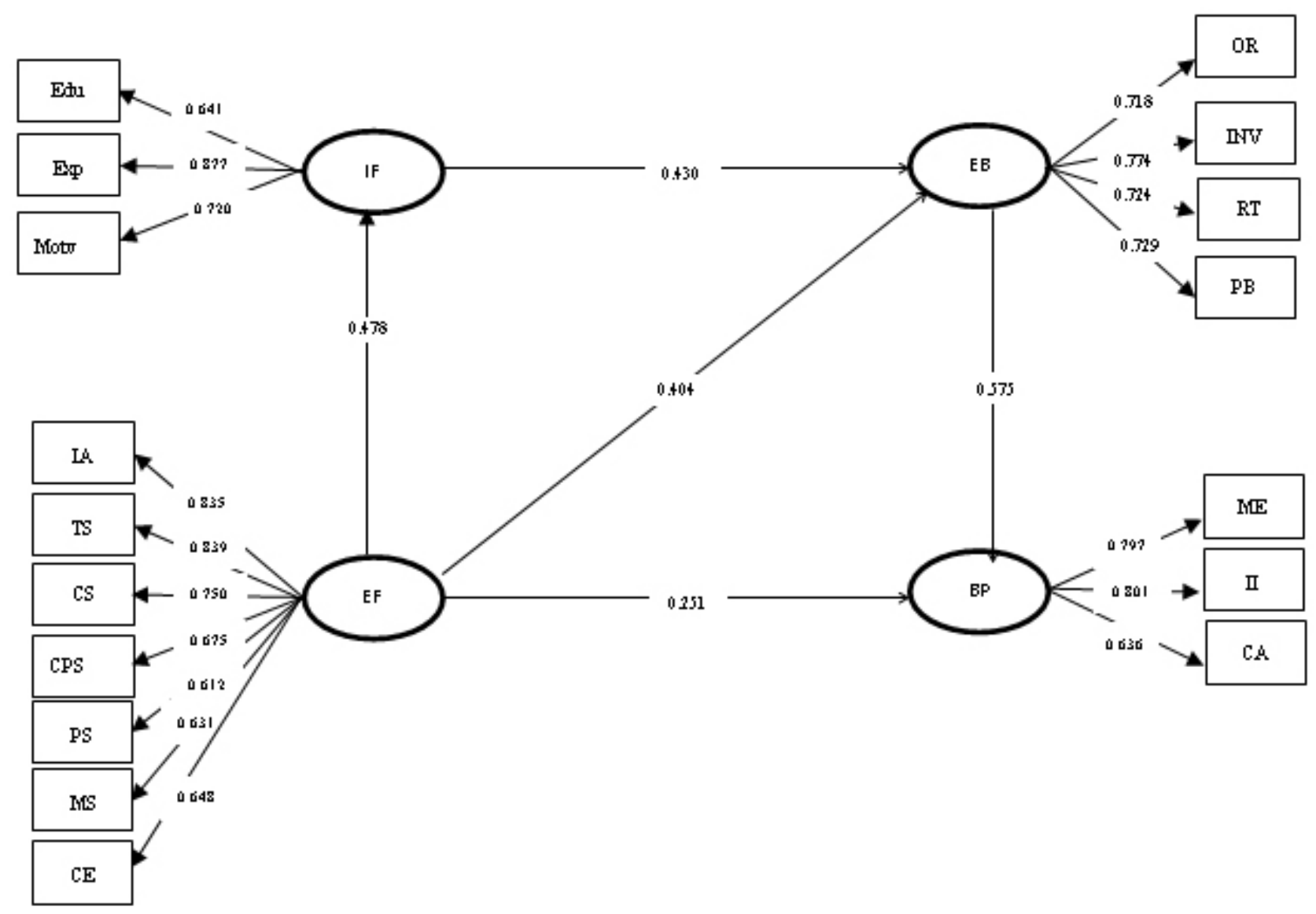

Figure 2. Standardized loading factor measurement model of the effects of individual factors, environmental factors, and entrepreneurial behavior on business performance cassava SMEs agroindustry

The second stage is the evaluation of structural model to see the relationship between latent variables with their constructs (Ghozali and Latah, 2013). The results obtained can be seen from the estimation of path coefficients and significant levels. In this research, the structural model obtained explained the effect of environmental factors on individual factors, individual factors on entrepreneurial behavior, entrepreneurial behavior on business performance, as well as the effect between environmental factors and entrepreneurial behavior factors on business performance. Causal relationship model between factors that effect directly or indirectly on entrepreneurial behavior and business performance can be seen in Figure 3.

Table 2 shows the results of hypothesis testing in which all hypotheses have t- value $>1.96$, while (?) the fifth hypothesis rejects $\mathrm{H} 0$. It can be concluded that all hypotheses have t-value $>1.96$ which means that the structural model evaluation of the research model are as follows: (1) hypothesis 1: individual factors (IF) have a positive effect on entrepreneurial behavior (EB); (2) hypothesis 2: environmental factors affect the individual factors; (3) hypothesis 3: environmental factors (EF) have a positive effect on entrepreneurial behavior (PK); (4) hypothesis 4: entrepreneurial behavior (EB) have a positive effect on business performance (BP); and (5) hypothesis 5: environmental factors (EF) have a positive effect on business performance (BP).

From the model, it can be seen that the effect of one latent variable to another latent variable is positive and real. As Ghozali and Latah (2013) points out that when viewed from the validity test, observed variables that have a $\mathrm{t}$-value of standardized loading factor $<1.96$, and standardized loading factor $<0.50$ are excluded from the model by estimating the model. Based on Figure 2, the model has been good at describing the actual data and conditions so that it can be adapted to the underlying theory. T-value validity in Figure 3 also shows that the variable in the model is able to measure what should be measured or the model is able to explain the relationships between variables. 


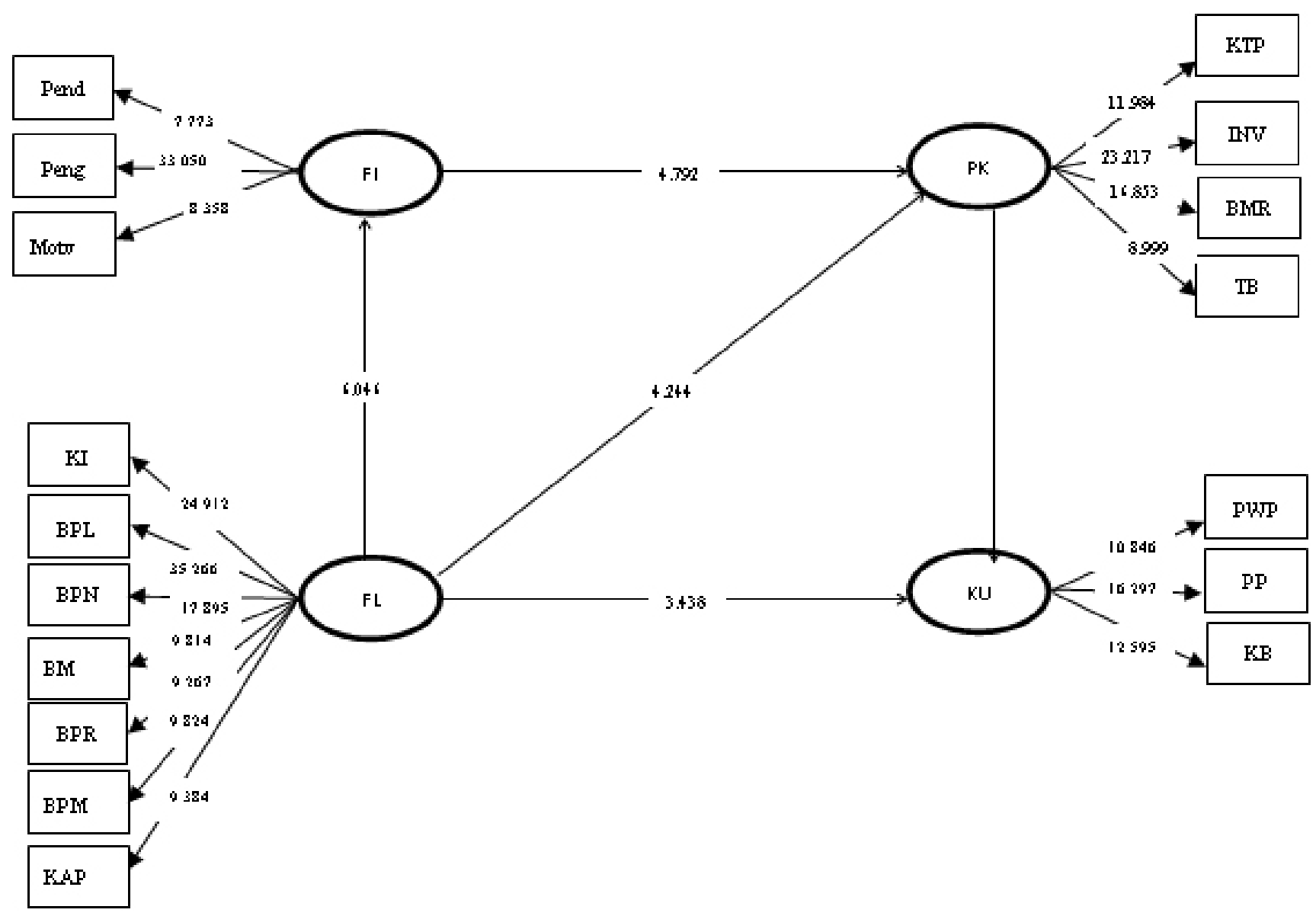

Figure 3. T-value of structural model of the effects of individual factors, environmental factors, and entrepreneurial behavior on business performance cassava SMEs agroindustry

Table 2. Structural model coefficient evaluation and its relation to the research hypothesis

\begin{tabular}{ccccc}
\hline Hypothesis & Variable & Loading Factor & $\mid$ t-value $\mid>1.96$ & Conclusion \\
\hline $\mathrm{H} 1$ & $\mathrm{IF} \rightarrow \mathrm{EB}$ & 0.429 & 4.792 & Significant \\
$\mathrm{H} 2$ & $\mathrm{EF} \rightarrow \mathrm{IF}$ & 0.478 & 6.046 & Significant \\
$\mathrm{H} 3$ & $\mathrm{EF} \rightarrow \mathrm{EB}$ & 0.404 & 4.244 & Significant \\
$\mathrm{H} 4$ & $\mathrm{~EB} \rightarrow \mathrm{BP}$ & 0.575 & 9.435 & Significant \\
$\mathrm{H} 5$ & $\mathrm{EF} \rightarrow \mathrm{BP}$ & 0.251 & 3.438 & Significant \\
\hline
\end{tabular}

\section{The Effects of Individual Factors, Environmental Factors and Entrepreneurial Behavior}

\section{Individual Factors}

Individual factors are formed by environmental factors with the effect coefficient 0.478 and t-value 6.046 which is bigger than t-table (1.96). This implies that the stronger the environment reflected by the availability of inputs, training support, counseling support, promotion support, marketing support, business regulation and cohesiveness among entrepreneurs, the stronger the level of individual characteristics of business actors. Individual factors are the factors that reflect entrepreneurial behavior. Based on the composition of influencing factors (Figure 3 ) it is found that individual factors directly influence entrepreneurial behaviors of cassava SMEs agroindustry entrepreneurs with the effect coefficient 0.429 with t-value 4.792 , which is bigger than t-table (1.96), meaning individual factors have a significant effect on entrepreneurial behavior. This is in accordance with the initial hypothesis that the individual factors have a positive and significant effect on entrepreneurial behavior. Individual factors are measured by indicator variables, namely education, experience and motivation. The most dominant indicator variable that measures individual factors of entrepreneurs is experience with the loading factor 0.877. This illustrates that in running cassava SMEs agroindustry, entrepreneurs have enough experience so 
they have big opportunities to develop their business. Cassava food processing cannot be done randomly, entrepreneurs need enough experience to be able to produce products that have good in taste and in accordance with the customers' tastes.

Increasing education, experience and motivation can grow entrepreneurial behavior of cassava SMEs entrepreneurs in achieving successful business. Education and knowledge improvement make entrepreneurs have a creative mindset, always want to create a new thing, try to find a solution to the problems encountered, and have the skills to communicate well. This finding is in line with Sumantri's (2013) research which states that education, age and experience are the most important factors in influencing the performance of entrepreneurial women's enterprises. The presence of high motivation can also enhance courage to take risks and to have a desire to earn greater revenue.

\section{Environmental factors}

Based on Figure 3, the environmental factors have positive and significant influence with the effect coefficient 0.404 and t-value 4.244 , which is bigger than t-table (1.96). It means environmental factors have a significant effect on entrepreneurial behavior. This is in accordance with the hypothesis that environmental factors have a positive and significant impact on entrepreneurial behavior in which environmental factors were measured based on indicators of input availabilities, training support, counseling support, promotion support, marketing support, capital support, business regulation, and cohesiveness among entrepreneurs. The dominant factor that reflected an environmental variable is training support. This shows that the training provided by the government is very influential in business activities. The form of training provided was training in food processing based on local raw materials, where the entrepreneurs were taught how to cultivate cassava well and use the component materials appropriately to fit the standards. Other forms of training ever given was entrepreneurial training and financial management training from the Financial Services Authority (OJK).

The results of this study showed that entrepreneurial behavior was directly influenced by individual factors, namely personal factors of entrepreneurs and external factors coming from the environment. This is in accordance with the result of Munizu (2010) research, which states that internal factors consisting of human resources have a positive and significant influence on the performance of micro and small enterprises and external factors consisting of government policy, socio-cultural aspects and economics, and aspects of the role of related institutions have a significant and positive influence on internal factors of micro and small enterprises. It means that the external environment affects the internal conditions in the business or business running.

\section{The Effects of Environmental Factors, Entrepreneurial Behavior and Business Performance}

\section{Environmental Factors}

The results of PLS analysis in this research showed that environmental factors had a positive and significant impact on business performance. This can be seen from the value of the effect coefficient, 0.251 with t-value 3.438 which is bigger than t-table (1.96). It means environmental factors significantly affect the business performance. The results of this study have been compatible with the hypothesis which states that there is a positive and significant relationship between the environment and business performance. It can be explained that the availability of input materials, counseling support, training support, capital support, promotion support, marketing support, business regulation, and cohesiveness among entrepreneurs will ultimately affect the performance of cassava SMEs agroindustry.

The role of government was considered to be quite meaningful by entrepreneurs in running their business, through training provided, entrepreneurs had more understanding about how to produce a quality product. In addition, monitoring was also done at least once a month to determine the improvement of business performance. The role of policies that supported business activities undertaken by entrepreneurs and support from related institutions were able to facilitate entrepreneurial activities so their business performance was expected to become better from time to time. Financial access was still less perceived by entrepreneurs. To get a loan, the entrepreneurs felt difficult to make a proposal because it took a long time to make it. Therefore, the entrepreneurs only relied on their business profits for the sustainability of the business. 


\section{Entrepreneurial Behavior}

Entrepreneurial behavior had a positive and significant effect on business performance with a coefficient of influence 0.575 and $t$-value 9.435 which is bigger than t-table (1.96). It means entrepreneurial behavior significantly affects the business performance. This is in line with Wahyuningsih (2015) research that stated that entrepreneurial behavior played an important role in improving business performance through the courage to take risks and persistence in doing business. The same result also found in Rakib (2008) that said that entrepreneurial attitude (behavior) very much determined the performance of small business. High discipline, creativeness, innovativeness, and the courage to take risks in every action contributed to the performance of small businesses.

Entrepreneurial behavior was reflected by four indicators: responsiveness to opportunities, innovation, the courage to take risks, and persistence in doing business. The biggest loading factor was shown by innovativeness. Innovativeness was the ability to think of new ideas, and then implemented it, so as to create a new product that is different from the one before. Based on the facts, the entrepreneurs have been able to create a different product than before which is just red balado chips. Currently the entrepreneurs have created many products made from cassava such as red balado chips, balado flavor durian chips, original chips, cheese flavored chips, dakak-dakak, ganepo and serundeng. Innovations were created not only in terms of products, but also in terms of shape and size of packaging. The entrepreneurs were also brave in taking risks; even when the price of raw materials was expensive, they still produced it to fulfill customer's demand. Some entrepreneurs anticipated price increases by increasing product prices or reducing product weight. The results of this study were similar to the results of research Noersasongko (2005) which stated that innovation and the courage to take risks had a dominant influence on business success.

\section{Business Performance}

The business performance of cassava processed business was explained by the expansion of marketing area, increased income and competitive advantage. Increased Income contributed the most to business performance with loading factor 0.801 . Although the increase in income was not high, the entrepreneurs were able to fulfill their daily needs, allocate the next capital and reduce the existing debt burden. The amount of income earned on average ranges between IDR3,000,000IDR5,000,000. The greater the increased income, the higher the desire of entrepreneurs to develop their business. Increased Income can occur if entrepreneurs always improve their production continuously to meet the consumer demand. Therefore, support from the government was needed in the provision of capital, facilities and infrastructure to support business sustainability. The expansion of the marketing area also contributed a substantial loading factor 0.797. The perception of business actors to the expansion of marketing area showed an increasing trend. This can happen because Padang city is famous as a center of cassava processed production so people's interest to buy also increased. It caused the entrepreneurs to decide to expand marketing areas that previously were only spread in the city of Padang and West Sumatra. Now it has reached other cities in Sumatra and Java and even to foreign countries such as Malaysia, Singapore and Australia. Government support is expected especially to create partnerships that helps the entrepreneurs to promote and market their products so that this product is not only known in Indonesia, but also in other countries.

\section{Managerial Implication}

Government's support and attention are needed to create a conducive business climate. This will ultimately motivate business actors to continue their business and improve their welfare, among others with several efforts:

1. The government should provide training and counseling support to entrepreneurs on business development about how to manage their business, make good financial records and process hygienic production.

2. Providing assistance in the form of facilities and appropriate infrastructure is also highly needed in business development, considering that this production is still done manually. The existence of these infrastructure facilities will motivate entrepreneurs to be able to produce higher. Capital assistance is also needed by entrepreneurs for the sake of business continuity. Capital is one reason why entrepreneurs are still afraid of enlarging their business. 
3. Facilitating entrepreneurs in developing marketing can create mutually beneficial partnerships to ensure the ease and sustainability of raw materials availability.

\section{CONCLUSIONS AND RECOMMENDATIONS}

\section{Conclusions}

Based on the results of the research, it has been found that (1) The performance of cassava SMEs agroindustry is determined by entrepreneurial behavior with the coefficient of entrepreneurial behavior effect 0.575 . The most dominant variable that reflects entrepreneurial behavior is innovative $(\lambda)$ 0.793, (2) entrepreneurial behavior is influenced by individual factors with the effect coefficient 0.430 . The most dominant variable that reflects individual factor is experience with loading factor $(\lambda)$ equal to 0.877 , (3) Individual factors are influenced by environmental factor with effect coefficient equal to 0.478 . The most dominant variable that reflects the environmental factors is training support ( $\lambda$ ) 0.838 . The stronger the environmental factor that is reflected by the availability of inputs, training support, counseling support, promotional support, marketing support, business regulation and cohesiveness among entrepreneurs, the stronger the individual characteristics level of the entrepreneurs.

\section{Recommendations}

Improving performance of cassava processing business is expected by all parties. Therefore, to improve the performance of cassava SMEs agroindustry requires the support of all parties (1) On individual factors, entrepreneurs can make comparative studies to increase their experience and knowledge on similar products, (2) On environmental factors, the entrepreneurs need to join intensive training and internships, so those activities are expected to increase the entrepreneurs' knowledge and skills in the development of the products they produce. (3) On entrepreneurial behavior factor, entrepreneurs need to improve innovative attitude through innovation, not only innovation in product form, but also innovation in the production process as well as on the form of packaging. New technologies need to be introduced to save time and to increase the production of processed cassava.

\section{REFERENCES}

Alma B. 2010. Kewirausahaan Edisi Revisi. Bandung: Alfabeta.

[Department of Manpower and Industry] Dinas Tenaga Kerja dan Perindustrian. 2015. Direktori dan Potensi Pangan UMKM di Kota Padang. Kota Padang: Pemerintah Kota Padang Dinas Tenaga Kerja dan Perindustrian.

Dirlanudin. 2010. Perilaku wirausaha dan keberdayaan pelaku usaha kecil industri agro: kasus di Kabupaten Serang Provinsi Banten. [disertasi] Bogor: Sekolah Pascasarjana, Institut Pertanian Bogor.

Gupta A, Muita RS. 2012. Relationship between Entrepreneurial Personality, Performance, Job Satisfaction and Operations Strategy: An Empirical Examination. International Journal of Business and Management 8(2): 86-95. https:// doi.org/10.5539/ijbm.v8n2p86.

Karunanithy K, Jeyaraman S. 2013. Impact of entrepreneurial characteristics on the organizational development of the small business entrepreneurs. Industrial Engineering Letters 3(6): 28-33.

Ghozali I, Latan H. 2013. Partial Least Square. Konsep, Teknik dan Aplikasi Menggunakan Program SmartPLS 3.0. Semarang: Badan Penerbit Universitas Diponegoro.

Mothibi G. 2015. The Effects of Entrepreneurial and Firm Characteristic on Performance of Small and Medium Enterprises in Pretoria. International Journal of Economics, Commerce and Management United Kingdom 3(3):1-8.

Munizu M. 2010. Pengaruh Faktor-Faktor Eksternal dan Internal terhadap Kinerja Usaha Mikro danKecil (UMK) di Sulawesi Selatan. Jurnal Manajemen dan Kewirausahaan 12(1): 33-41.

Noersasongko E. 2005. Analisis pengaruh karakter individu, kewirausahaan dan gaya kepemimpinan terhadap Kemampuan usaha serta keberhasilan usaha pada usaha kecil batik di Jawa Tengah [disertasi]. Malang: Universitas Merdeka Malang.

Puspitasari. 2013. Pengaruh perilaku kewirausahaan petani anggrek terhadap kinerja usaha: kasus di Kecamatan Gunung Sindur dan Parung, Kabupaten Bogor, dan Kecamatan Serpong, Kota Tangerang Selatan [tesis]. Bogor: Institut Pertanian Bogor. 
Rakib M. 2008. Analisis faktor-faktor yang memengaruhi kinerja usaha di Kota Pare-Pare. Jurnal Aplikasi Manajemen 8(4):984-993.

Riyanti BP. 2003. Kewirausahaan Dari Sudut Pandang Psikologi Kepribadian. Jakarta : PT.Grasindo.

Sapar. 2006. Faktor-faktor yang berhubungan dengan perilaku kewirausahaan pedagang kaki lima [tesis]. Bogor: Institut Pertanian Bogor.

Sugiyono. 2010. Metode Penelitian Kuantitatif Kualitatif dan R\&D. Bandung: Alfabeta.
Sumantri. 2013. Faktor-faktor yang berpengaruh terhadap kinerja usaha wirausaha wanita: suatu studi pada industri pangan rumahan di Bogor. Jurnal Manajemen Teknlogi 12(3): 252-277. https://doi.org/10.12695/jmt.2013.12.3.3.

Wahyuningsih DC. 2015. Pengaruh perilaku kewirausahaan terhadap kinerja usaha bawang goreng di Kota Palu Provinsi Sulawesi Tengah. [tesis]. Bogor: Institut Pertanian Bogor. 